\title{
Space Production Management and Social Tendency in the Traditional Mining of Oil, Bojonegoro Regency
}

\author{
Ichmi Yani Arinda Rohmah \\ Sociology Department \\ Universitas Airlangga \\ Surabaya, Indonesia \\ arindaichmi186@gmail.com
}

\begin{abstract}
Spatial production management in the region has an impact on various sectors of society. If the spatial production management conducted by the holder of power is building up the area, providing an easier way for the community in achieving the welfare of life, then the production management of the space is done successfully. However, if spatial production management is done for the unilateral sake of the ruling and disadvantages of society, then what arises is disorder and social tendencies that are deviant. Research conducted by researchers is about how the management of space production by the government in the area of traditional oil mining. In addition, the research also focused on the social tendencies of miners that took place in traditional oil mining. The research used qualitative research method approach of case study type. The object of research in Wonocolo Village Kedewan District Bojonegoro District. Using interview data retrieval techniques, observation and documentation. The result of this research is to produce data about the management of spatial production by the power holder (government) in the sector of traditional oil management of Wonocolo Village, Bojonegoro Regency. The result of the research shows the existence of dominant space representation not only on the practice of space but also the representational space. Spatial production practices that create abstract spaces by power holders encourage social tendencies to engage in community-based spatial production practices and traditional oil mining activities.
\end{abstract}

Keywords—component, formatting, style, styling, insert

\section{INTRODUCTION}

Spatial plan Bojonegoro Bojonegoro regulated by local governments. As stipulated in the Law of the Republic of Indonesia Number 26 of 2007 concerning spatial arrangement and Government Regulation (PP) number 26 the year 2008 concerning the national spatial plan, it is necessary to be spelled out in provincial and district spatial plan.

In connection with the Act and the Regulations Pemering, the districts Bojonegoro administration has the full right to produce spatial Bojonegoro properly. One of them in terms of production mem spatial extraction of oil in the districts Bojonegoro, fully regulated by the local government Bojonegoro.

Oil mining land in Bojonegoro terda pat in several locations, as described in the Provincial Regulation on Spatial Planning (RT/RW) Bojonegoro Year 2011-2031
Chapter 3 District Regional Spatial Structure Plan Article 30 paragraph 3 of the Appropriation Mining Region Oil and Gas. One of the areas mentioned as an area where there is a traditional oil mining is Wonocolo Village Kedewan District Bojonegoro District.

Traditional oil mining in Wonocolo village has been in operation since before 1945 until now in 2017. Almost 90\% of the people of Wonocolo Village have livelihoods as traditional oil miners. The definition of traditional oil mining is oil mining which is done in the traditional way and using traditional tools, but since 2000 the miners also used diesel machine.

Representation of the production management of the traditional oil-mining room conducted by the Bojonegoro regency not only on the practice of space but also on the representational space. The government cooperated with the State Owned Enterprises (SOEs), which handles about mining and oil management also operates oil mining in Wonocolo with modern mining system.

In the area of traditional oil extraction also built an abstract space (the space from the viewpoint of spatial planners mining) of unknown function and its use for the community of miners and non-mining in Wonocolo. So it raises several factors that lead to social tendencies of society in addressing the implementation of government policy and the extraction of oil.

Social tendencies or trends in society's behavior is heavily influenced by miners mining production management space by governments and elites e konomi.Among the behavioral tendency is a mining community in the area of oil mining practices Wonocolo village that still has not been friendly to the environment. In addition, many mining communities who put false hope for the planning governance of traditional oil extraction chamber is in progress is not maximal.

The problems described make the research conducted in conjunction with the management of the production of mining spaces by the government and the resulting consequences become very important. Based on the background of the existing problems, the research conducted in this research question, namely how the management of mining space traditional oil production in Bojonegoro and how the social tendencies of society in addressing the implementation of government policy and the extraction of 
oil. In the data analysis conducted by researchers using the study of Henri Lefebvre's theory of production space thinking.

There are several previous studies studied by researchers as a comparison and differentiator research conducted by current researchers and previous researchers. As the previous research conducted by the first researchers Rizha Nahdia Naumi and Agus Trilaksana Department of History Education, Faculty of the the Social Sciences State University of Surabaya in the journal Avatara, e-Journal History Education Volume 3, No.1, March 2015. In his research has the formulation of the issue of the background behind doing the traditional oil mining in Wonocolo Village, secondly, about the process of traditional oil mining is done. The results show that traditional oil mining is done because in Wonocolo Village there are many old wells of Dutch heritage that can be reused. Oil mining was originally done in the traditional way, but after about 1980 using the technology of diesel engines and used cars as an oil pump drive (1).

The second prior research was conducted by PLHIV Adhitama, Bambang Santoso, and Riyanto majoring in Public Administration, Faculty of Administrative Sciences, Brawijaya University, Malang. The results of the study are published in the journal Public Administration Vol. 2, No. 3. The research is about the contribution of the oil and gas sector in Bojonegoro regency. The results of the research indicate that the contribution of the oil and gas sector in Bojonegoro Regency is very large, such as to increase local revenue through DBH and Regional Balancing Fund, opening vacancies, and as a driver of regional development(2).

\section{RESEARCH METHOD}

The research setting was conducted in the traditional oil mining area in Wonocolo Village, Kedewan Sub-district, Bojonegoro District, Indonesia. Selection of research setting is because the area has a uniqueness to be researched. Bojonegoro regency is one of the districts that has a wealth of natural oil and gas resources. Traditional and largest oil mining is done in the area of Kedewan Village, Bojonegoro.

Approach method of research is a qualitative method; the qualitative method has the perspective to understand and explain the social reality (3). Social reality may include the fact that appears in awareness, knowledge, and confidence men (4). This type of research is a case study with a case study of intrinsic, i.e., cases reviewed has an aspect of specificity and simplicity, attracting interest, but cannot represent other cases (5).

Data collection techniques used are interviews, observation, and documentation. Interviews were conducted on village apparatus that became the object of research and the traditional oil miners. Observations conducted are nonparticipant types, researchers observe the implementation of production management of oil mining space and its impact on the social tendency of miners in managing the oil mining area. Documentation by the researchers, collecting documentation of mining areas and community mining activities, collecting documentation in the form of letters relating to the focus of research cases.
Data analysis of research result by using the analysis model formulated by Miles and Huberman that is data collection, data reduction, display data, and conclusion drawing / verification. Here is a map of the research data analysis concepts Miles and Huberman (6):

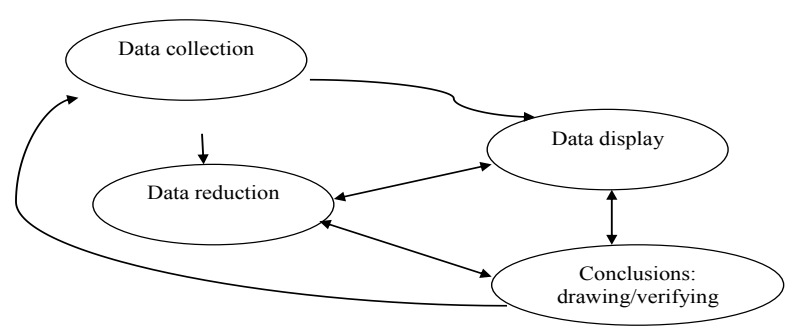

Fig. 1: Miles and Huberman'S Data Analysis

\section{A. Thinking Framework}

The Frameworks in the research is the result of the argument think by using a scientific theory as the premise of the study (7). The research on space production management and social tendency in the traditional mining of oil in Bojonegoro regency has the following framework.

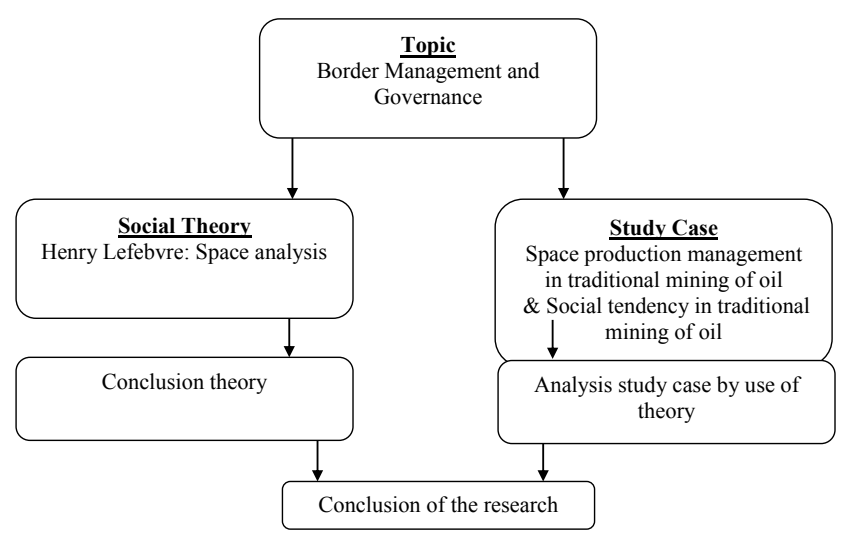

Figure 2: Research Framework

Research on the topic of Border Management and Governance has a case study on space production management in the traditional mining of oil and Social tendency in the traditional mining of oil. In the case study analysis, the researcher uses social theory proposed by Henri Lefebvre, that is a theory about spatial analysis until the conclusion of the final result of the research.

The social theory proposed by Henri Lefebvre is the theory of spatial analysis. Henry Lefebvre explains that in space reproduction there is a practice of space dominated by the representation of space. The representation of space that dominates not only the practice of space but also on the representational space. In practice space also produces an abstract space which often excludes the representational space of its existence. 


\section{RESEARCH FINDINGS}

\section{A. Selecting Space Production Management in Traditional Mining of Oil}

Oil fields in Bojonegoro Regency are located in several locations, as described in the Regional Regulations on Spatial Plans (RTRW) of Bojonegoro Regency Year 20112031 Chapter 3 District Spatial Plans Article 30 of the Mining Allocation Zone, paragraph 1.b reads : Mining designation area as referred to in Article 25 letter e concerning Area of Cultivation of mining type, area of approximately 905 (Nine hundred five) Ha, including: area of oil and gas mining.

Continued on the explanation of paragraphs $3 . a$ and $b$ which reads: The oil and gas mining designated area as referred to in paragraph 1.b includes modern mining in the area of Sukoati Block in Bojonegoro and Kapas sub-districts and Cepu Block area in Ngasem sub-district, and traditional mining in the village Wonocolo Hargomulyo village and subdistrict Kedewan Beji Village and surrounding areas.

Focus on traditional oil mining in Wonocolo Village. Previously note that Wonocolo is one of the other villages that have permission to manage oil traditionally. Wonocolo villagers have characteristics as people characterize different village communities with urban communities. Urban communities and rural communities are often distinguished gradually. Rural communities have a more characteristic feature of society have close social ties, have a system that emphasizes family life (8).

Like the village community, they still have a high desire to involve themselves in agriculture and mining that is done traditionally; it is also different from the urban community. Although today many modern industries are built in the region of Bojonegoro regency. A very influential subject in modern industry is the change in the productive base of society. Urban communities began to no longer engage in the affairs of agriculture or artisanal mining carried out by the villagers (9).

Oil mining in Bojonegoro is explored traditionally and modernly. Some of the most modernly explored sources of oil are managed by the government in cooperation with foreign companies. While oil exploration is traditionally managed by the people of Bojonegoro. There are several sources of oil traditionally mined by the community, one of them is in Wonocolo Village, Kedewan District, Bojonegoro District.

The geographical location of the traditional Wonocolo oil mining area is located on the Wonocolo plateau, about 2 kilometers from the community settlement. The petroleum mining field is a land owned by forestry that has been legally permitted to be opened for traditional oil enhancement. The assumption of traditional oil mining conducted by mining communities is far from settlements; miners considered traditional oil exploration in Wonocolo not to be a contributing factor to environmental pollution.

Regarding the production management of the traditional oil mining space, it covers the maintenance of the environment in the mining area. As mentioned in Bojonegoro Regency Regulation No. 6 of 2012 Article 1, paragraph 10 . The neighborhood is unity with all things space, power, state, and living beings, including humans and their behavior, which affect nature itself, the continuity of livelihoods and human well-being and other living beings.

The relationship between the public and institutions based on the law as in view of the objective social noted that it is a product of the community itself and not from the institution (10). Such statements may be justified if the formulation of legal regulations is enforced according to the needs of the community, not unilaterally based on the legal interests of the law.

Spatial representation in traditional Wonocolo oil mining has a significant influence on some sectors in the lives of miners. First, with regard to land ownership of oil resources, land used for the extraction of oil is government land managed by Perhutani. Based on land or land ownership rights, the ownership status of community mining land is limited to borrowing from the Perhutani party. Thus, in the exploration of oil mining, the government and state-owned companies also have the right to mining in several oil sources. The majority of mining was done by the company is in a modern way.

Just as modernity described by Anthony Giddens, to which modernity is an uncontrollable world (Giddens, 1991: 16) (11). Modern oil mining companies are better able to operate more sophisticated oil production tools out of control. As long as production equipment can produce abundant mining output and the company has sufficient capital to manage the mine, modern mining companies will be better able to control oil mining more quickly than mining by traditional miners.

It becomes a problem on the part of the miners who hold the view that traditional oil mining land is the full right of the community. If there is a government participating in exploring the oil mines, in the eyes of the people the action is unfair. This is because the majority of the people of Wonocolo Village have livelihoods as oil miners. Moreover, with regard to the governance of the traditional oil mining space, it is not entirely the mining community to know the government regulations governing the practice of oil mining in Wonocolo.

Not only are regulations on mining practices unknown, but miners also do not know the rules of environmental governance in the oil mining space.How can Seb spoke by one of the traditional oil miners Mr. Oka when asked researchers associated with rules governing oil penabangan space:

"Mboten wonten peraturan resmi saking pemerintah mbak, lan dereng jelas notone" (There are no official regulations of the government miss, and it is unclear arrangement).

The statement expressed by one of the traditional oil miners on behalf of Mr. Okta indicates that the local government's regulation on the spatial layout of traditional oil in Wonocolo has not been recognized. Whereas the regulation has been described in the local government regulations on the arrangement of mining space. Government regulations on spatial are mentioned among the Bojonegoro Regency Regulation No. 26 Y ear 2011 Paragraph 5 of article 30 of the Mining Designation Region, chapter 36, section 44 . 
Article 30 of the mining areas of paragraph 1 (a) reads area of allotment of mining as referred to in Article 25, paragraph e of the cultivated area (Kawasan allotment of mining), an area of approximately 905 (Nine hundred and five) Ha, including: a) Kawasan allotment of mining minerals and rocks, b) oil and gas mining areas. Paragraph 3 (three) reads mining allotment area of oil and natural gas as referred to in paragraph (1) b, including: a) modern mining in the area of Block Sukoati in the District and the District Cotton Bojonegoro and Cepu area in District Ngasem; and b) traditional mining in Wonocolo Village, Hargomulyo Village, and Beji Village, Kedantor District and surrounding areas.

Elucidation of article 36 on the determination of the district strategic area Paragraph 4 (four) mentioned that the district strategic region of the interest of economic growth, as referred to in paragraph (1) letter a (the interest of economic growth), including one on the final point is the area of strategic minerals mining and oil and gas.

Based on the explanation of Article 36 paragraph 4, the oil mining in Bojonegoro Regency is managed in a modern way by the company or traditionally by the community miners group, the oil mining is one of the natural resources that become the commodity as the fulfillment of the economic needs of the regional community.

Article 44 of the general provisions of zoning regulations space pattern, in paragraph 23, explained that the general provisions of zoning regulations area of allotment of mining, as referred to in paragraph (13) d (area of allotment of mining), prepared as follows: a) allowed for an increase in the ability to perform supervision of production volume, $b$ ) permitted for increased capacity to control environmental and social impacts, c) permitted use of mineral, energy and other mineral resources for the welfare of the people, d) permitted for post-mining rehabilitation of land, e) mining of mineral, energy, and other mineral resources with the provisions of law in the field of environmental management, and f) prohibited activities that cause environmental damage.

Based on Article 44, paragraph 23, explain the provisions on zoning management of the pattern of oil mining space in modern and traditional.Explained that the mining was allowed to run in a specific area if it has the ability to improve and control the volume of production, in that case is expected by the mining is done in addition to obtaining mining output is maximized, the miners also can provide surveillance on the volume of oil production so that no occurrence oil scarcity.

In Article 44, paragraph 23 also explained that mining could be done if able to control the impact of mining on the natural and social environment.Conducting mining in order to prosper the people. Able to conduct mining in accordance with the Law in the field of environmental management. And not damage the environment.

Secondly, the representation of space resulted in the economic sector mining community. The existence of restrictions on traditional oil mining areas affects the income of miners. Miners whose majority have only livelihoods as miners complained a lot when the source of crude wells no longer produces oil in abundance. So that the income of miners in accordance with the results of oil obtained, sometimes the oil obtained large amounts, sometimes also oil obtained a small amount.

Third, the representation of space that produces an abstract space in traditional oil mining region. Traditional oil miners initially strongly expected and believed the development of educational attractions in oil mining sites could help miners to increase their economic earnings. However, since the planned educational attraction will be built to date, the educational tourism room in the oil mining area can not be realized, there are many factors that become obstacles, such as the cost of development factors and the lack of clean water sources. Here is the village head said Wonocolo Kedewan District of Bojonegoro:

"Sementara ini wisata Teksas Wonocolo belum optimal pengoperasiannya, hal itu karena masih mencari sumber air bersih yang dapat dimanfaatkan karena dianggap belum memadai. Pengelola wisata sementara ini ditangani oleh Pemda Bojonegoro dan perusahaan PT.Pertamina milik pemerintah. (While this is not optimal Wonocolo Texas travel operation, it is because they are looking for a clean water source that can be utilized as deemed inadequate. Tour manager while this is handled by the local government PT.Pertamina Bojonegoro and government-owned companies)."

Hamlet Head Wonocolo testified that the local government has set up an effort Bojonegoro as a solution to the traditional oil miners, that when faced with a shortage of oil, then the miners work in Texas Wonocolo as a new livelihood space in the field of mining education tourism. However, because the local government program Bojonegoro Regency in an effort to build a mining education tourism places cannot run maximally, then the miners think the program is just a hoax.

The production management of the traditional oil mining space has had an impact on several sectors of community life, particularly the economic and socio-cultural sectors. Social tendencies can be seen from the habits of mining communities in doing mining-related practices, ranging from mining, mine oil management, and to the distribution of mining products.

The existence of restrictions on the mining area, unstable oil prices, the absence of a double profession owned miners other than mining. This is what makes the miners experienced a tendency social to conduct mining practices with their own strategies, ranging from the mining process crude oil, crude oil processing, until the transaction mined in some places that are able to give a higher price than the price specified by the company as a proper container of mining proceeds.

\section{B. Selecting Space Production Management in Traditional Mining of Oil}

Community involvement in the management system Ruan $\mathrm{g}$ is also governed by local regulation Bojonegoro No. 6 of 2012, concerning the transparency of governance, income, environment, and social responsibility from enterprise business activities of oil and gas, Chapter V of the environment Article 7, paragraph 2, which states that the preparing the disaster risk reduction standard as referred to in paragraph 1 before, the company involves the government and the community. 
Management-production of oil mining space traditionally done by Government $h$ and cooperation with the state-owned company PT.Pertamina social impact in the community mining. Among the social tendencies of mining communities in view of policy government and the realization of mining practices with traditional systems, to the extent of mining practices with ecological sustainability.

Social tendency or propensity mining community in his view of government policies, the public perceives the government's policy to set the pattern space or land oil extraction in the village Wonocolo not quite fair. This is because mining communities who feel unfair view the policies of the local government to assess the land used for oil mining are traditionally more narrow than oil fields managed by modern companies. In addition, the public does not agree if the government companies participate in the operation of oil mining in the area of traditional oil mining in Wonocolo. The following is a statement of one of the miners:

"Mboten enter bantuan opo-opo teko perusahaan pemerintah iku. Perusahan senengane ngepek tanah e wong. Perusahaan yo ngekei wong-wong sing cerek. Mbiyen yo onok tapi yo ora teko kene. (There is no any assistance from the government company. The company take of land people. Companies ya give people who are close to him alone) )"

Government companies that perform in modern mining has the legal habitus to be realized because it has received permission from the government. In addition modern companies have sufficient capital to conduct mining in a modern way without many risks and obstacles. It is a manifestation of a habitus relation with the capital of a modern oil company to get permission to operate in oil mining. As Pierre Bourdieu explains about the habitus.Habitus is often associated with capital because habitus has a role as a multiplier of various kinds of capital. Habitus, in reality, able to create capital (symbolic) that exist in and of themselves (12)

The tendency of the mining community in conducting mining practices with tra system divisional not fully taking into account environmental sustainability. This is due to lack of socialization by the government in an effort to preserve the environment in the area around the mine. In addition, the management of the production of mining spaces by the government is not entirely accessible to mining communities; it can trigger internal conflict between local government and mining communities. The act of madness (not their concern for the environment) the name of rationality and irrationality are the two subject that can not be separated (13).

The existence of local problems that are still not resolved, especially the latent conflict between the mining community with the government, and the problems of petroleum shortages that have started cannot be mined. Today many mining communities are doing urbanization or migrating from rural to urban. To determine the relationship between the villagers and the city needs to do a survey in a different time period (13). If in a certain period of time villagers who urbanize to the city do not return to the village, it can be argued that the relationship between rural and urban communities in a single city room is going well. But the concern is that many villagers want to stay in the city and do not want to live in the village anymore. This can be estimated by looking at the changing demographics of the growing world population. They mostly live in big cities and left the countryside (14).

\section{CONCLUSION}

The Oil mining in Wonocolo Village Bojonegoro District has been operating since before 1945. The management of mining land is managed by the community traditionally with the permission of local government. Production management of oil mining space in Wonocolo Village Bojonegoro District is fully owned by the local government of Bojonegoro. The existence of management and regulations established by the local government of Bojonegoro on the production of traditional oil mining space in Wonocoloo gave a significant influence on the social life of miners.

Using Henry Lefebvre's space production theory, a case study on the production of the traditional oil-mining chamber is described. Mentioned in theory that the reproduction of space there is a practice of space which is dominated by the representation of space. The representation of space that dominates not only the practice of space, but also on the representational space. In practice space also produces an abstract space which often excludes the representational space of its existence.

District governments have represented mining space in accordance with the interests of the regions and communities. Spatial practices that have been undertaken by district governments are not entirely acceptable to the public. One is the spatial practice by the district government to divide the oil-mining areas in the legitimate Wonocolo Village for the benefit of the Wonocolo community as a major livelihood field, and mining land to be managed by the local government in cooperation with BUMN. The practice of the division of oil mining areas in Wonocolo village resulted in social tendencies in the community, especially miners. One of them is the social tendency of the community who ignores the rules of the management of oil-based mining space of ecology.

Spatial representation by the local government on the oil field in Wonocolo Village also creates an abstract space. The abstract space is planned as one of the solutions offered by the local government to the traditional oil miners when the oil source has run out. However, the abstract space that is planned to be built as a tourist place for education of oil management has not been resolved with the maximum. The idea of development of educational place of oil mining education is considered failed by society because it has long only a discourse and there is no follow-up development maximally..

\section{REFERENCES}

[1] Naumi Rizha Nahdia, Agus Trilaksana, (Traditional Oil Mining in Wonocolo Village, Kedewan Ward, Bojonegoro Regency) "Pertambangan Minyak Tradisional di Desa Wonocolo, Kecamatan Kedewan, Kabupaten Bojonegoro Tahun 1970-1987”. e-Journal Avatara Pendidikan Sejarah. Vol.3 No.1 (2015).

[2] Adhitama Odha, Bambang Santoso, Riyanto, (The Contribution of Oil and Gas to the Local Revenue in Bojonegoro Regency) "Kontribusi Sektor Migas Terhadap Penerimaan Daerah dalam Rangka Meningkatkan Pembangunan Daerah di Kabupaten Bojonegoro", Jurnal Administrasi Publik (JAP). Vol.2. No.3 (2015). 
[3] Upe Ambo, Damsid, (The Principles of Multiple Researches) "Asasasas Multiple Researches”, Yogyakarta: Tiara Wacana, 2010.

[4] Bungin Burhan (Ed.), (Qualitative Research Methodology, Methodological Actualization toward Various Contemporary Cases) "Metodologi Penelitian Kualitatif Aktualisasi Metodologis ke Arah Ragam Varian Kontemporer," Jakarta: PT. RajaGrafindo Persada, 2001.

[5] Denzin Norman K., Yvonna S. Lincoln, "Hanbook of Qualitative Research,"Yogyakarta: Pustaka Pelajar, 2009.

[6] Sugiyono, (Qualitative Research Method and R\&D) "Metode Penelitian Kuantitatif Kualitatif dan R\&D," Bandung: Alfabeta, 2013.

[7] Purwanto, (Social Research Instrument and Development Education and Use) "Instrumen Penelitian Sosial dan Pendidikan Pengembangan dan Pemanfaatan," Yogyakarta: Pustaka Pelajar, 2010.

[8] Soekanto Soerjono, (Sociology An Introduction) "Sosiologi Suatu Pengantar," Jakarta: PT. RajaGrafindo Persada, 2006.

[9] Thorns David C., "The Transformation of Cities Urban Theory and Urban Life," New York: Palgrave Macmillan, 2002.
[10] Susan Novri, (Sociology of Conflict An Introduction) "Pengantar Sosiologi Konflik," Jakarta: Prenadamedia Group, 2014.

[11] Ritzer George, (Sociological Theory from Classic to Postmodernism) "Teori Sosiologi dari Sosiologi Klasik Sampai Perkembangan Terakhir Postmodern,” Yogyakarta: Pustaka Pelajar, 2014.

[12] Harker Richard, Cheelen Mahar, Chris Wilkes (Ed.). (Practice, An A Comprehensive Introduction on The Thpught of Pierre Bourdieu) "Praktik, Pengantar Paling Komprehensif Kepada Pemikiran Pierre Bourdieu," Yogyakarta: Jalasutra, 2010.

[13] Foucault Michel. Kegilaan dan Peradaban. Yogyakarta: Ikon Teralitera, 2002.

[14] Foucault M., "Madness and Civilization: A History of Insanity in The Age of Reason," New York: Vintage, 1988.

[15] Bowman Alan, Andrew Wilson (Ed.), "Settlement, Urbanization and Population,” United Kindom: Oxford University Press, 2011.

[16] Turner Bryan S. (Ed.). (Social Theory from Classic to Postmodernism) "Teori Sosial dari Klasik Sampai Postmodern," Yogyakarta: Pustaka Pelajar, 2012. 